\author{
Mateja ŠMID HRIBAR \\ Jani KOZINA \\ David BOLE \\ Mimi URBANC
}

\title{
Javno dobro, skupni viri in skupno: vpliv zgodovinske zapuščine na sodobno dojemanje v Sloveniji kot tranzicijski družbi
}

Namen prispevka je proučiti in jasno opredeliti pojme javno dobro, skupni viri in skupno. V članku smo na podlagi prostorsko-časovne analize, intervjujev in delavnic med splošno in strokovno javnostjo osvetlili dojemanje javnega dobra in skupnega v Sloveniji kot tranzicijski družbi. Analiza je pokazala, da na razumevanje teh pojmov med splošno javnostjo še vedno močno vpliva poudarjanje socialne pravičnosti, enakosti in dostopnosti dobrin za vse iz obdobja socializma, kar je lahko v nasprotju s pravico do zasebne lastnine. Neustrezno upravljanje dobrin, ki so dojete kot javno dobro, v resnici pa so skupni viri, lahko vodi v konflikte in razvrednotenje skupnih virov, sčimer bomo izgubili prednosti, ki nam omogočajo kakovostnejše ži- vljenje. Ker smo od omejenih naravnih virov življenjsko odvisni, je treba o njih nujno ozavestiti splošno in strokovno javnost, izpostaviti ranljivost teh virov in pojasniti, da ne morejo biti dostopni vsem v neomejenih količinah. V mednarodnem okolju želimo s predstavljenim slovenskim primerom prispevati $\mathrm{k}$ boljšemu razumevanju človeškega vedenja in pričakovanj do javnega dobra in skupnih virov v postsocialističnih tranzicijskih družbah.

Ključne besede: javno dobro, skupno dobro, skupni viri, skupno, skupna lastnina, prostor, upravljanje, tranzicijska družba, Slovenija 


\section{Uvod}

Kulturna krajina, naj bo podeželska ali urbana, kot življenjski prostor prinaša dobrine na različnih ravneh in za različne skupine ljudi. Lastnike zanima predvsem njen ekonomski vidik, nelastniki pa imajo pričakovanja glede javnega in skupnega dobra (Šmid Hribar idr., 2015). Tako je zaradi polpretekle zgodovine in tranzicijskega stanja slovenske družbe del slovenske javnosti prepričan, da dobrine, kot so na primer gozdni sadeži, gozdovi, mestne zelenice, obale rek in jezer ter podobno, pripadajo vsem in jih lahko vsi tudi uporabljajo, saj meni, da so javno dobro. Z njimi se ne strinjajo lastniki zemljišč, v glavnem kmetje, ki želijo omejevati rabo tovrstnih dobrin. Neustrezno dojemanje javnih dobrin se nanaša tudi na urbana območja. Pomenske razlike med pojmoma javno in skupno dobro niso jasne. Splošna javnost ju večinoma uporablja sinonimno, pri čemer prevladuje izraz javno dobro, kar bomo uporabljali v nadaljevanju. K zmedi dodatno prispeva tipologija dobrin, po kateri sta v ekonomskem in okoljevarstvenem diskurzu ključni lastnosti dobrine manjša ali večja dostopnost in manjše ali večje zmanjševanje z rabo (Ostrom in Ostrom, 1977; Ostrom, 2005). Zgoraj omenjene dobrine torej v resnici niso javno dobro, temveč skupni viri, saj so prosto dostopne in se njihova razpoložljivost z uporabo manjša.

Namen tega prispevka ni preverjanje akademskih pojmov javnega in skupnega dobra ter skupnih virov med splošno in strokovno javnostjo, ampak želimo z njim osvetliti, da splošno razumevanje javnega dobra - ne glede na poimenovanje - in z njim povezanih pravic včasih ni ustrezno in je posledica preteklega dojemanja upravičenosti do dobrin. Po drugi strani so pritiski lastnikov po omejevanju dostopa do dobrin čedalje izrazitejši, kar ustvarja razkorak med pravicami do zasebne lastnine, določene po 33. členu Ustave RS (Ustavni zakon o dopolnitvi III. poglavja Ustave Republike Slovenije, Ur. l. RS, št. 75/2016), in privilegiji, pridobljenimi v prejšnjem sistemu. Dejstvo je, da v socialistični preteklosti pridobljeni privilegiji prinašajo prednosti, ki jih sodobna zakonodaja delno ohranja in lastnikom omejuje uporabo nekaterih dobrin. Tako 67. člen Ustave RS (Ustavni zakon o dopolnitvi III. poglavja Ustave Republike Slovenije, Ur. 1. RS, št. 75/2016) določa, da mora zakon določiti način pridobivanja in uživanja lastnine tako, da je zagotovljena njena gospodarska, socialna in ekološka funkcija. Skladno z navedenim smo postavili hipotezo, da slovenska družba, ki spada med tranzicijske, številne prosto dostopne dobrine v kulturni krajini, ki so pravzaprav skupni viri, dojema kot javno dobro, do katerega so upravičeni vsi, pri čemer trči ob pravice do zasebne lastnine. Predvidevamo, da je tako dojemanje posledica polpretekle zgodovine oziroma političnih, ideoloških, gospodarskih in družbenih sprememb.
Nepoznavanje skupnih virov in neustrezno upravljanje lahko vodita $\mathrm{v}$ konflikte glede uporabe in razvrednotenje virov ter posledično $\mathrm{v}$ izgubo prednosti, ki omogočajo kakovostnejše življenje. Zato menimo, da v tranzicijskih družbah, kakršna je slovenska, potrebujemo jasno opredelitev pojmov javnega dobra in skupnih virov. To bo prispevalo $\mathrm{k}$ razumevanju, da nekatere dobrine, čeprav so prosto dostopne, niso javno dobro, da jih ni v neomejenih količinah in da so ranljive, zaradi česar ni samoumevno, da so vedno vsem na voljo. Ustrezno poznavanje razlike med javnim dobrom in skupnimi viri je pomembno, saj vpliva na pričakovanja in vedenje javnosti do dobrin, ki imajo ključno vlogo pri dobrobiti in kakovosti življenja. Tovrstne dobrine so skupni viri predvsem zato, ker lastniki ne omejujejo dostopa do njih, tega pa ne storijo, ker je takšne vire a) fizično težko ograditi (npr. gozd) in $s$ tem omejiti njihovo nabiranje (npr. gozdne sadeže) ali b) ni v slovenski tradiciji, da bi fizično omejevali dostop in njihovo rabo.

\section{Cilji članka so:}

1. pojasniti, zakaj se v slovenski tranzicijski družbi pojavljajo nesporazumi o dojemanju javnih dobrin in skupnih virov, in pokazati, kako se to kaže $\mathrm{v}$ konfliktih, povezanih $\mathrm{z}$ dostopnostjo do skupnih virov,

2. osvetliti, kako širša in strokovna javnost v Sloveniji razumeta pojma javno in skupno dobro, in

3. opozoriti na jasno razliko med javnim dobrom in skupnimi viri, da bomo razumeli in znova ozavestili, da prosto dostopne dobrine, ki so skupni viri, niso javno dobro in zato ne morejo biti dostopne vsem $\mathrm{v}$ neomejenih količinah.

\section{Teoretska izhodišča}

Izraz javno dobro v slovenski zakonodaji ni jasno opredeljen, uporablja se nekonsistentno in nesistematično (Vugrin, 2005; Šmid Hribar idr., 2015). V že omenjenem ekonomskem in okoljevarstvenem diskurzu so raziskovalci v drugi polovici 20. stoletja $\mathrm{v}$ iskanju opredelitve javnega dobra dobro opredelili s kriterijema (ne)izključenosti in (ne)konkurenčnosti (Samuelson, 1954, navedeno v Ostrom, 2010; Musgrave, 1969, navedeno v Desmarais-Tremblay, 2013), ki so ju pozneje natančneje opredelili in zamenjali s kriterijema manjše/ večje dostopnosti in manjšega/večjega zmanjševanja z uporabo (Ostrom, 2010). S križanjem kriterijev (ne)izključenosti in (ne)konkurenčnosti sta Musgravova (Musgrave in Musgrave, 1973) s teoretičnim modelom opredelila štiri tipe dobra, pri čemer sta se poleg zasebnega in javnega dobra pokazali še dve obliki: dobro, katerega razpoložljivost se z uporabo ne manjša, a nimajo vsi dostopa do njega, in dobro, katerega razpoložljivost se z uporabo manjša, a je težko preprečiti dostop. Za drugo obliko se je sprva uporabljal termin skupno dobro. Vendar 
je ta termin, čeprav je bil že od antične Grčije del zahodne politične misli (Lee, 2018) in širše uporabljen koncept, ki ga obravnava večina političnih mislecev (Dupré, 1993), ohlapen, nenatančen in so mogoče zlorabe (Jaede, 2017). Po mnenju Mansbridgeeve (2013) pomen koncepta izvorno ni dorečen. Zadevo še otežuje dejstvo, da se pojem skupnega dobra pogosto zamenja z javnim dobrom in javnimi interesom (Mansbridge, 2013).Zaradi proste dostopnosti in omejenosti je ta kategorija dobrine postala zanimiva za raziskovalce. Pomemben pečat sta ji dala zlasti Vincent in Elinor Ostrom (1977; Ostrom, 2005) ter njuni sodelavci, ki so jo poimenovali skupni viri (ang. common-pool resources). Po opredelitvi je skupni vir $\gg$ naravni vir ali sistem vira, ki ga je ustvaril človek in ki je dovolj obsežen, da je drago (vendar ne nemogoče) potencialnim uporabnikom preprečiti, da bi z uporabo pridobili koristi « (Ostrom, 1990: 30). Omenjene lastnosti niso odvisne od družbenopolitičnih dejavnikov, temveč so neločljivo povezane s skupnimi viri. Skupni viri se zaradi proste dostopnosti pogosto zamenjujejo z javnim dobrom.

Nepoznavanje skupnih virov vodi v neustrezno upravljanje in uporabo virov. Neustrezna zakonodaja pri tem ni v pomoč. To lahko vodi v poslabšanje ali celo uničenje vira, na kar je opozoril Hardin (1968) v znamenitem prispevku Tragedy of the commons. V njem je izpostavil usodno človeško lastnost, in sicer da vsak posameznik išče le svoje koristi. Sodobna primera tragedije skupnega sta čezmerni ribolov v Jadranskem morju (Fromentini, 2009; Colloca idr., 2013) in gospodarjenje z denacionalizirani gozdovi na Slovaškem (Kluvánková in Gežík, 2016). Čezmerna uporaba skupnega vira ali neprimeren poseg vanj imata lahko otipljive družbenogospodarske posledice (Rodela, 2012). Hardinovemu pristopu je uspešno nasprotovala Ostromova (1990), ki je zagovarjala, da se je tragediji skupnega mogoče izogniti z ustreznim upravljanjem. Izpostavila je (1990, 2000, 2010), da ne trg oziroma neoliberalni ekonomski model ne država niti zasebniki prek koncesijskih pogodb niso ponudili želenih rešitev za trajnostno upravljanje skupnih virov. Na podlagi številnih primerov iz različnih delov sveta je Ostromova ugotovila, da skupne vire lahko upravljajo tudi lokalne skupnosti (Ostrom, 1990; 2010). Leta 2009 je za spoznanje, da ljudje ob spoprijemanju z omejenimi viri zmorejo delovati in sodelovati v skupno korist, prejela Nobelovo nagrado (Ostrom, 2010; Anderies in Janssen, 2013). V Sloveniji takšna sodelovanja poznamo v obliki agrarnih skupnosti, ki so več stoletij upravljale skupna zemljišča oziroma skupno v širšem smislu (Vilfan, 1996; Petek in Urbanc, 2007; Bogataj, 2012), bile v času socialistične ureditve razpuščene, po osamosvojitvi Slovenije pa se zopet oživljajo. Termin skupno (ang. commons) dodatno vpliva na zmedo med pojmoma javno in skupno dobro. Nanaša se na dobrine v skupni lasti, ki jih upravljajo skupnosti, ob uporabi skupnostnih praks, s točno določenimi pravili in se pogosto napačno razumejo kot skupno dobro. Na zmedo je pred leti opozorila McKeanova (2000), ki je izpostavila, da je skupna lastnina le posebna oblika zasebne lastnine v skupni rabi. Po njenem mnenju je treba razlikovati med dobrinami, pravicami in pravnimi subjekti/zasebnimi lastniki, ki posedujejo stvari. Dobrine, pravice in pravni subjekti so lahko zasebni ali javni.

Zmeda pri razumevanju pojmov javnega dobra in skupnega v Sloveniji je predvsem posledica zgodovinsko-institucionalnega konteksta. Ta učinek se imenuje prostorsko-časovna odvisnost (ang. path dependency) in ga označuje zaporedje zgodovinskih dogodkov v prostoru, ki vodijo v sedanje institucionalne vzorce ali verigo dogodkov. $Z$ opredelitvijo zgodovinskih dogodkov v nekem prostoru in njihovega medsebojnega učinkovanja lahko razkrijemo prostorske, družbene in druge vzorce (Godina, 2015). Heinmiller (2009) meni, da je prostorsko-časovna odvisnost pri proučevanju skupnostnih praks pri upravljanju skupnih virov premalo raziskana, a lahko ključno vpliva na upravljanje virov. Analiza skupnostnih praks v zgodovinskem kontekstu na Portugalskem (Gomes Lopes idr., 2013) je pokazala, da je sedanje stanje skupnih zemljišč tesno povezano s ključnimi zgodovinskimi obdobji. Sočasno se je pokazalo sosledje oblikovanja odnosov do virov in pravil, ki so vodila v različne parcelacije in pravne oblike skupnih zemljišč. Godina (2015) izpostavlja, da je bil pomen prostorsko-časovne odvisnosti prezrt pri načrtovanju in izvajanju družbenih sprememb v postsocialističnih družbah, vključno s slovensko. Kot glavni razlog navaja ideološko obarvan odnos do zgodovine, ki temelji na ideji diskontinuitete s socializmom. Enako lahko trdimo tudi za socialistično in industrijsko družbo v razmerju do agrarne družbe pred letom 1945. Dodatno zmedo povzročata ključna koncepta polpretekle zgodovine: družbena lastnina in samoupravljanje. Zakon o združenem delu (Ur. l. SFRJ, št. 53/1976), ki je vpeljal koncept družbene lastnine, ne podaja opredelitve, iz komentarja (Grahek, 1988: 14) pa izhaja: »Delavci si tako prilaščajo del dohodka, vendar ne na lastninski, temveč na delovni podlagi.« $S$ prenehanjem pogodbe o delu je ugasnila tudi pravica do dohodka iz določene družbene lastnine. Samostojno upravljanje lastnine je bilo bistvo delavskega samoupravljanja, uzakonjenega leta 1950 (Zakon o upravljanju državnih ..., Ur. l. FLRJ, 1950). Oba koncepta sta v spremenjenem pomenu še vedno v zavesti ljudi (Toplak, 2014) in vplivata na pojmovanje dobrin. Navedene trditve vsaj deloma lahko posplošimo na druge postsocialistične države srednje in vzhodne Evrope (Premrl idr., 2015; Markuszewska, 2018), v katerih so zaradi družbenogospodarskih sprememb kot posledica spremembe režima in decentralizacije oblasti nastale številne vrzeli med lastninsko zakonodajo in pravicami v praksi. Razkorak med de iure in de facto pri upravljanju dobrin vodi do krčenja širših interesov v korist posameznikov, kar povzroča slabšanje kakovosti in zmanjševanje zalog skupnih virov (Sikor, 2004). 


\section{Metode}

V 4. poglavju članka smo kot metodološki okvir uporabili koncept prostorsko-časovne odvisnosti in na podlagi pregleda literature utemeljili tri zgodovinska obdobja, ki vplivajo na dojemanje pojmov javnega dobra in skupnega $\mathrm{v}$ slovenski družbi, ki jo še vedno označuje postsocialistična tranzicija. $S$ tem pristopom želimo opozoriti na vlogo (ne)ustreznega razumevanja lastnosti naravnih virov in pokazati, da jih je mogoče trajnostno upravljati. V 5. poglavju članka smo na podlagi intervjujev in delavnic navedli primere javnega in skupnega dobra na pilotnih območjih ter izpostavili prednosti in konflikte, ki jih ustvarjajo te dobrine. Zanimalo nas je, kaj domačini na pilotnih območjih in strokovna javnost razumejo kot javno in kot skupno dobro. Jeseni 2015 smo na treh pilotnih območjih (krajevne skupnosti Bevke, Čadrg in Kosovelje) izvedli po eno delavnico $\mathrm{z}$ domačini o koristih krajine ter o javnem in skupnem dobru v njihovih naseljih. Od marca do novembra 2016 smo izvedli 31 poglobljenih strukturiranih intervjujev $\mathrm{z}$ domačini in $23 \mathrm{z}$ deležniki iz javnega sektorja, ki se pri svojem delu posredno ali neposredno ukvarjajo $s$ krajinami (s področja razvoja podeželja, varstva zavarovanih območij, narave in kulturne dediščine, kmetijstva, gozdarstva in lova). Intervjuji so v povprečju trajali 53 minut in so obsegali tri sklope vprašanj o odnosu posameznika do kulturne krajine, pri čemer se je tretji sklop nanašal na vprašanja o javnem in skupnem dobru v krajini, njihovih koristih in morebitnih konfliktnih situacijah.

\section{Vpliv prostorsko-časovnih odvisnosti na razumevanje javnega dobra in skupnega v Sloveniji}

V Sloveniji lahko razmejimo tri pomembna zgodovinska obdobja, ki so povezana s širšimi političnimi, gospodarskimi in demografskimi spremembami. Klemenčič $(1989 ; 1997)$ na podlagi sektorske teorije (Small in Witherick, 1986) piše o različnih razvojnih stopnjah - demografskih, družbenogospodarskih, geografskih in drugih -, ki so pustile odtise na krajini in ljudeh. Zlasti so zanimive družbenogospodarske stopnje, ki s spreminjanjem deležev v sektorjih zaposlitve nakazujejo prehod od agrarne prek industrijske do postindustrijske (informacijske) družbe. Slovenska družba je bila do šestdesetih let 20. stoletja pretežno agrarna, nato je sledila bliskovita in kratka industrializacija do devetdesetih let 20. stoletja, tej pa je sledila terciarizacija družbe. Odločilno vlogo sta imela socialistična ureditev po drugi svetovni vojni in prehod $\mathrm{v}$ tržno gospodarstvo po osamosvojitvi Slovenije. Skladno s tem smo se odločili, da dojemanje javnega dobra in skupnega prikažemo na podlagi treh zgodovinskih mejnikov: agrarnega obdobja do konca druge svetovne vojne (do leta 1945), obdobja socializma, kolektivizacije in industrializacije (1945-1991) in obdobja samostojne Slovenije (po letu 1991), ki je zaznamovano s terciarizacijo gospodarstva, individualizacijo družbe in prehodom $\mathrm{v}$ tržno gospodarstvo.

\subsection{Agrarna družba (do leta 1945)}

Agrarna družba je gospodarsko temeljila na primarnem sektorju (kmetijstvo, lov, ribolov in gozdarstvo). Prevladovala je razdrobljena zasebna lastnina, v manjšem obsegu pa so bili pašniki in gozdovi v posesti vaških skupnosti, ki so te dobrine uporabljale skupno (Vilfan, 1996). Ker so bile skupnosti od virov odvisne, so večinoma pazile, da jih ne izčrpavajo ali poškodujejo (Rodela, 2012). Slovenija ima bogato tradicijo skupnih zemljišč, ki so imela velik gospodarski pomen, povezan s preživetjem ne le posameznih družin, ampak celotnih vasi (Petek in Urbanc, 2007). Skupna zemljišča po nastanku segajo še v dobo plemenske ureditve in so se prek fevdalizma ponekod ohranila do današnjih dni. Obči državljanski zakonik Habsburške monarhije iz leta 1812 je razlikoval med a) javnim dobrom, kamor so spadale stvari, prepuščene v rabo vsem državljanom (na primer javne ceste, napajališča), b) občinskim dobrom, do katerega so bili upravičeni občani, in c) občinskim premoženjem, iz katerega naj bi se pokrivali občinski stroški (Vilfan, 1996). Vendar že Vilfan opozarja, da je različne oblike skupne lastnine težko razvrstiti v omenjene pravne kategorije in da so se pravice do koriščenja krajevno razlikovale. Krovna termina zajemata več regionalnih in časovnih različic; skupno zemljišče: »komunšna «, »komunela « in »gmajna « (prav tam: 237) in agrarna skupnost: »soseska « (Petek in Urbanc, 2007), »sose(d) ska «, »srenja «, »jus «, »skupnina « (Bogataj, 2012). Poleg gospodarjenja na skupnih zemljiščih je agrarna skupnost skrbela za vzdrževanje, na primer urejanje poti in napajališč (Ravnik, 1998). Na splošno se bile do konca fevdalizma pravice na skupnih zemljiščih dokaj enotne in vezane na pripadnost lokalni skupnosti, po njegovem zatonu pa so se začele diferencirati. Vilfan (1996) izpostavlja, da so se ostanki nekdanjih vaških skupnosti ohranili v primerih skupnostnega upravljanja skupnih zemljišč. Pri upravljanju je prevladoval gospodarski vidik, ki pa je bil zaradi nizke stopnje tehnološkega razvoja večinoma okoljsko vzdržen. Kljub temu so se pojavljale tudi prakse, ki so vodile v osiromašenje ali celo izgubo naravnega vira. Eden takšnih primerov je izguba šote na Ljubljanskem barju. V začetku 19. stoletja, tik pred intenzivnim osuševanjem, naj bi bilo na njem do 1500 ha šotišč (Pavšič, 2008). Franciscejski kataster kaže, da so bili med letoma 1824 in 1827 številni mokrotni travniki in pašniki skupna zemljǐ̌ča (Šmid Hribar, 2016). Z osuševanjem in delitvijo zemljišč po letu 1830 pa so nekdanji skupni pašniki prehajali v zasebno last. Zaradi gospodarskih dobičkov so lastniki začeli v drugi polovici 19. stoletja šotišča intenzivno izkoriščati. Kljub ocenam, da zaloge šote zadoščajo 


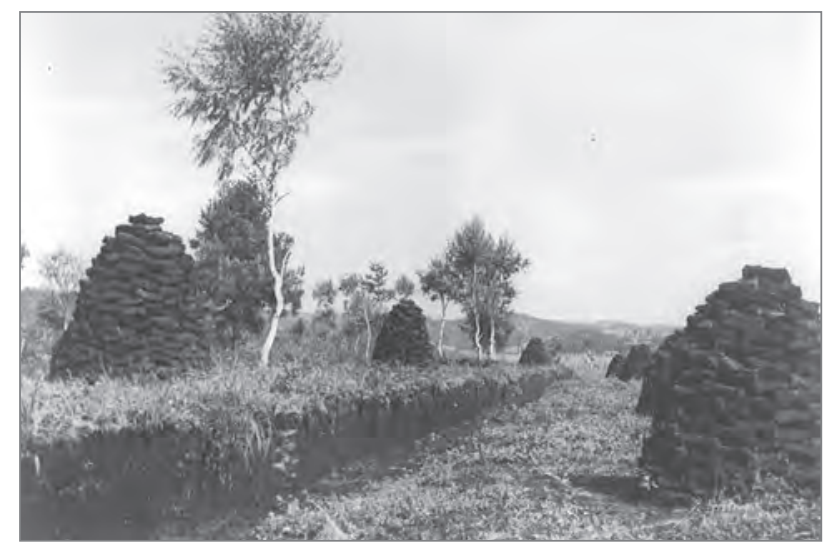

Slika 1: Rezanje in sušenje šote na Ljubljanskem barju (vir: arhiv Krajinskega parka Ljubljansko barje)

za 229 let, je šota $\mathrm{v}$ nekaj desetletjih pošla in posledično so se barjanska tla znižala (Melik, 1927). Poplavna ogroženost Ljubljanskega barja se je povečala in spremenile so se funkcije krajine in ekosistemske storitve, posledice pa občutijo vsi zdajšnji prebivalci (Šmid Hribar, 2016).

\subsection{Industrijska družba (1945-1991)}

Ključni vpliv na današnje dojemanje in upravljanje javnega dobra in skupnega ima obdobje socializma, ki so ga spremljale temeljite strukturne in ideološke reforme družbene, politične in gospodarske ureditve. Pomembni sta zlasti nacionalizacija in posledična razlastitev večjih posestnikov. Z zemljiškim maksimumom jim je bilo dovoljeno obdržati največ 35 hektarov (Zakon o agrarni ..., Ur. l. LRS, št. 10/1948), od leta 1953 pa le še 10 hektarov obdelovalnih zemljišč (Zakon o kmetijskem ..., Ur. l. FLRJ, št. 22/53). Razlastitev je poleg kmetov zajela tudi agrarne skupnosti (Zakon o agrarnih skupnostih, Ur. l. LRS, št. 52/1947; Zakon o razpolaganju ..., Ur. l. SRS, št. 7/1965), s čimer je bila prekinjena kontinuiteta načina upravljanja omejenih naravnih virov. Czerny (2014) na primeru izbrane agrarne skupnosti Škrbina-Rubije-Šibelji predvideva, da je odsotnost kontinuiranega skupnega upravljanja agrarnih skupnosti vplivala na razumevanje njihovih članov. Pri tem izpostavlja razlikovanje med upravljavskimi cilji pasivnih in aktivnih članov agrarne skupnosti. Aktivni člani dajejo prednost gospodarskim ciljem, pasivni člani pa okoljskim. Hkrati oboji ocenjujejo komunikacijo kot pomembno pri odločanju v agrarni skupnosti. Prepoznavajo tudi pomen usklajevanja glede rabe skupnih virov, kar je po njihovem mnenju poglavitno za preživetje agrarne skupnosti na dolgi rok (prav tam). Agrarna reforma, ki je povzročila razlastitev velikih posestnikov, je obenem vplivala na kolektivizacijo in vzpostavitev velikih državnih sistemov, kot so socialistične zadruge, kmetijski kombinati in državna gozdna podjetja (Jepsen idr., 2015; Premrl idr., 2015). Nastal je velik razkorak med povprečno 200 ha velikim kme- tijskim kombinatom in povprečno 5,2 ha velikim kmečkim gospodarstvom (Drozg, 2007).

Podobno kot v drugih državah vzhodnega bloka je bila za Slovenijo po drugi svetovni vojni značilna uvedba centralnoplanskega gospodarstva (Jepsen idr., 2015). Zasebno lastnino sta zamenjali državna in družbena lastnina (Urbanc, 2002). Moč odločanja se je s posameznikov, kmečkih gospodarstev in lokalnih skupnosti prenesla na državno raven (Partlič, 1989), z uvajanjem družbene lastnine in delavskega samoupravljanja pa na zaposlene v podjetju (Šetinc, 1979; Toplak, 2014). $\mathrm{Z}$ uvajanjem novih oblik lastnine so se začele krhati stoletja trajajoče in nastajajoče vezi med omejenimi viri in njihovimi lokalnimi skupnostmi, te so bile tudi njihove dejanske upraviteljice. Posledično se je začelo izgubljati znanje o značilnostih virov. Odgovornost za njihovo upravljanje je bila prenesena predvsem na državne ustanove, ki zaradi fizične in/ali kognitivne oddaljenosti niso bile tako dovzetne za trajnostno upravljanje. Eden prvih kritikov povojne kmetijske politike je bil po mnenju Partličeve (1989) Pučnik, ki se je že leta 1963 v tedaj ideološko spornem prispevku $\mathrm{O}$ dilemah našega kmetijstva spraševal o ciljih kmetijske politike: ali je to urejena preskrba s hrano ali odprava zasebne lastnine in uvedba kolektivne pridelave (Pučnik, 1963, navedeno v Partlič, 1989: 433). Negativen odnos do kmeta kot zasebnega proizvajalca (Urbanc, 2002; Razpotnik Visković in Seručnik, 2013) in načrtno ustanavljanje industrijskih podjetij po vsej Sloveniji sta vplivala na obsežno socialno preslojevanje iz agrarnih $\mathrm{v}$ neagrarne dejavnosti ter $s$ tem povezano urbanizacijo oziroma demografsko in prostorsko rast mest (Drozg, 2007). Razdrobljenost posesti, tudi kot posledica agrarne reforme, je povzročila oblikovanje obsežnega sloja polkmetov, ki so zaradi šibke gospodarske moči ohranjali drobno posest, pestrost kmetijskih krajin in ekstenzivno obdelovanje zemljišč (Urbanc, 2002) ter delovali zaviralno pred intenzivno deagrarizacijo. $S$ tem so imeli pomembno vlogo pri vzdrževanju tradicionalne kulturne krajine (Razpotnik Visković in Seručnik, 2013).

$\mathrm{Z}$ industrializacijo družbe in deagrarizacijo je začel v ospredje stopati mestni prostor (Drozg, 2007), v katerega se je prenesla problematika urejanja skupnega. Rezultat nedomišljenih strukturnih in ideoloških reform je še viden na primeru javnih zelenih površin ob večstanovanjskih stavbah (Zlatkova, 2015; Simoneti, 2016), ki naj bi meščanom omogočale kakovostnejše življenje in jih povezovale $\mathrm{z}$ naravo, a v zadnjih desetletjih postajajo vse bolj ogrožene.

\subsection{Postindustrijska družba (po letu 1991)}

Postindustrijska družba se je v Sloveniji razvila po letu 1991, ko je število zaposlenih v storitvenih dejavnostih rastlo hitreje od števila industrijskih delavcev (Klemenčič, 1989; 1997). Po- 


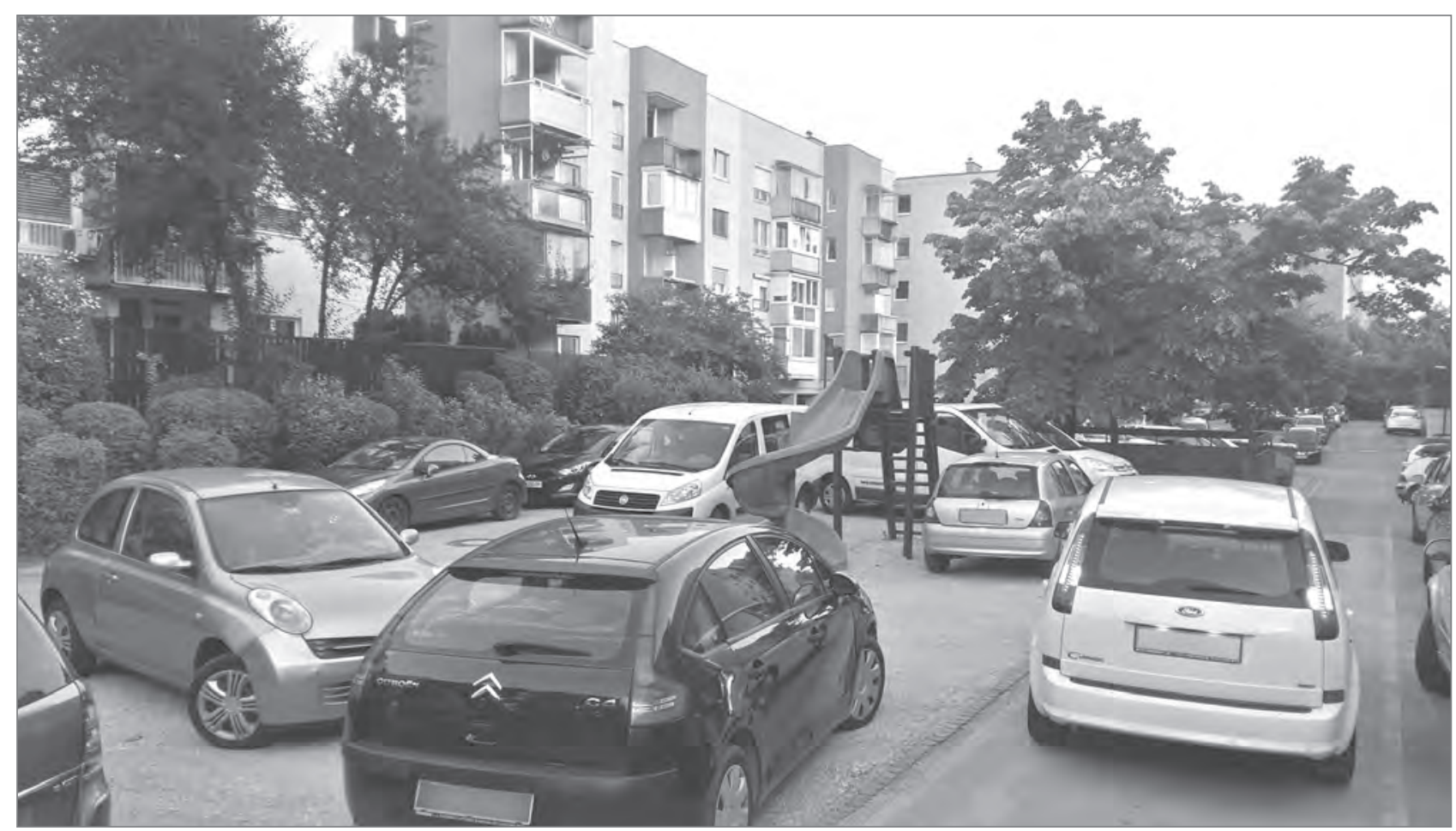

Slika 2: Stanovanjske zelene urbane površine, ki so se začele pojavljati v obdobju socializma, so pomembno urbano skupno, hkrati pa tudi skupni vir, zato jih je treba upravljati (foto: Peter Stavanja).

litične, družbene in gospodarske spremembe, ki so sledile osamosvojitvi in prehodu iz totalitaristične socialistične družbene ureditve v demokracijo in tržni kapitalizem (Drozg, 2007), ter zamenjava vrednostnih usmeritev družbe in posameznikov, povezanih z zmanjšsevanjem pomena kolektivizacije in naraščanjem individualizacije, so prinesle številne posledice.

$\mathrm{Z}$ vidika javnega dobra in skupnega sta ključni predvsem dve vrsti procesov. Prva se nanaša na odpravo družbene lastnine kot prevladujoče oblike lastniških razmerij iz socialističnega obdobja, druga pa na obujanje načinov skupnostnega upravljanja omejenih naravnih virov, ki se je izvajalo že v agrarni dobi. Odpravo družbene lastnine sta spremljali denacionalizacija in privatizacija, med katerima je pomembna vsebinska razlika. Pri prvi so bila lastniška razmerja razmeroma jasna in razumljiva. Premoženje se je vrnilo oškodovancem ali njihovim dedičem (Premrl idr., 2015) in vzpostavilo se je stanje pred nacionalizacijo. Pri privatizaciji pa je bilo lastništvo ohlapnejša kategorija, družbeno lastnino in nadzor nad produkcijskimi sredstvi pa je zamenjala razpršena in nepregledna zasebna lastnina. Neustrezna prerazdelitev bogastva in moči med pripadnike politične in gospodarske elite je lahko vodila v divjo privatizacijo (Lorenčič, 2009) ter slabšo kakovost vodenja in upravljanja državnega premoženja. Zadnje je značilno za vse nove države članice Evropske unije (Tomšič in Vehovar, 2012). Pozornost privatiziranja se je od nastanka gospodarske krize od državnih podjetij premaknila predvsem v prostor (zemljišča), energetiko, vodo, ki imajo lahko lastnosti skupnih virov in so ključni za preživetje. Denacionalizacija je obudila načine upravljanja skupnih zemljišč iz obdobja pred industrijsko družbo. Zakonodaja, sprejeta po osamosvojitvi Slovenije, omogoča ponovno vzpostavitev agrarnih skupnosti ter vračanje odvzetega premoženja in pravic (Petek in Urbanc, 2007). Vendar imajo zaradi slabo premišljenega Zakona o denacionalizaciji iz leta 1991, po katerem naj bi bila zemljišča vrnjena individualnim dedičem, agrarne skupnosti številne težave pri izvedbi sodnih postopkov, saj zakon vodi k privatiziranju nekoč skupne posesti in $s$ tem $\mathrm{v}$ verjetno spremembo uporabe tovrstnih zemljišč (Šmid Hribar idr., 2015). Po navedbah Cerarja idr. (2011) naj bi bilo v postopkih nacionalizacije $\mathrm{v}$ socializmu ukinjenih in razlaščnih od 1.000 do 1.500 agrarnih skupnosti, pri čemer obseg njihovih zemljišč ni znan. Premrl (2013) je navedel, da je v registrih upravnih enot zavedenih 638 agrarnih skupnosti, od tega potencialno aktivnih 547 , za dodatnih 48 postopki vračila premoženja še niso bili končani. Agrarnim skupnostim je bilo vrnjenih 77.486,47 ha zemljišč, kar je 3,67 \% ozemlja Slovenije (Premrl, 2013).V nasprotju z agrarno dobo, ko je bil pomen skupnih zemljišč zlasti gospodarski, v sodobnem času v ospredje prihajata ohranjanje in vzdrževanje ekološkega ravnovesja, biotske raznovrstnosti, tradicionalne kulturne krajine in podeželja nasploh (Petek in Urbanc, 2007; Jepsen idr., 2015; Šmid Hribar idr., 2015).

Z nedokončano privatizacijo, preobrazbo komunalnih služb in izvajanjem javne službe urejanja javnih zelenih površin lahko povežemo slabše vzdrževanje starejših stanovanjskih sosesk, ki 
jim brez celovite prenove preti razvrednotenje. Občine brez posebnih usmeritev, meril in pogojev za razdelitev površin med javne in zasebne so pri urejanju zelenih površin sosesk ravnale različno. V prostoru se to kaže v slabem vzdrževanju, prisvajanju, preurejanju in špekulantskih nakupih. Za zdaj poslabšanje kakovosti v starejših soseskah slovenskih mest še ni kritično, vendar lahko slabo vzdrževanje vodi v zmanjšanje možnosti za nove ureditve, $v$ skrajnem primeru tudi v nepovratno izgubo javnih zelenih površin (Simoneti, 2016). V Sloveniji postajajo pereča težava tudi različne oblike rekreacije $\mathrm{v}$ gozdu, med katerimi je priljubljeno nabiranje gozdnih sadežev. Nezadovoljstvo lastnikov gozdov je še večje, če nabiralci in rekreativci niso domačini. Jeseni 2016 so se v nekaterih krajih razvile tako imenovane kostanjeve vojne, ko so se jezni domačini zaradi pretiranega nabiranja kostanja, malomarnega parkiranja in vožnje zunaj prometnih cest uprli obiskovalcem (Omladič, 2016).

\section{Javno in skupno dobro v Sloveniji 5.1 Dojemanje javnega in skupnega dobra med domačini}

Večina domačinov na vseh treh pilotnih območjih slabo razlikuje med pojmoma javno in skupno dobro. Intervjuvanka iz Bevk pravi: $\gg V$ bistvu ne ločim to zelo dobro, ker je to zame zelo podobno. « V̌asih isto stvar hkrati razumejo kot javno in skupno dobro. Po podrobnejšem spraševanju se je izkazalo, da domačini pretežno skupno in javno dobro opredeljujejo le z lastninsko pravico ali pravico do uporabe dobrine. Javno dobro je po večinskem mnenju dobrina, ki je v javni lasti, za katero ni treba plačati in jo lahko uporabljajo vsi. Skladno $s$ tem javno dobro razumejo kot javne površine, ki so last vseh: na primer zemljiščca v lasti občine, občinska lastnina, ceste in poti, korita/napajališča za napajanje živine, vodnjak, kal, lokev, infrastruktura, prostor za smetnjake, zemljišča Sklada kmetijskih zemljišč, pokopališče, spomeniki, razgledišče. Prebivalci tudi vodo dojemajo kot javno, ne kot skupno dobro. Med javnimi dobrinami domačini izpostavljajo tudi storitve, ki so namenjene vsem, npr. javno zdravstvo, gasilci, bolnica, šole.

Pod pojmom skupno dobro domačini razumejo tisto, kar uporabljajo le krajani posameznega naselja: naravne vire, skupna zemljišča, zaprte ali odprte prostore in infrastrukturo ter stvari, ki so jih naredili, zgradili ali vzpostavili v skupnih akcijah v sklopu vaške skupnosti in za njihovo uporabo. »Skupno dobro je vse, kar skupaj naredimo, « meni intervjuvanec iz Kosovelj. Kot glavne primere skupnega dobra so povsod izpostavljali skupen zrak, vodo, mir, dostopnost do dediščine. Ključni so skupno lastništvo, skupno delo, koristi in uporaba. Po mnenju domačinov so skupno dobro v Čadrgu pitna voda in vaški vodovod, skupna zemljišča, kjer je možnost paše, ekološko kmetijstvo, priprava drv na skupnih zemljiščih, razgledišč $s$ klopjo, prostor, na katerem so sadili in sadijo orehe, sirarna, korita za napajanje živine. V Kosoveljah so skupno dobro skupni vodnjaki za zalivanje vrtov, ceste, pešpoti, tudi lokev, prostor za kurjenje kresa, prostor za smetnjake, parkirni prostor, tudi zasebni vrt, ki ga odprejo in želijo deliti z drugimi, optični kabel $s$ hitrim prenosom podatkov, nove zastave ter gobe in zelišča. V Bevkah so kot skupno dobro izpostavili nekatere kraje, pomembne za varstvo narave, pitno vodo in vodno zajetje, zdravilne rastline in možnosti druženja v prostorih, ki so jih pridobili s skupnimi močmi, kot so gasilski dom, športni park, vrtec, šola, cerkev, pokopališče. Po mnenju domačinov jim vse omenjene dobrine, podobno kot javno dobro, izbolǰ̌ujejo kakovost življenja in prinašajo koristi.

Na vseh treh pilotnih območjih poznajo konflikte, povezane z rabo javnega in skupnega dobra. Največkrat je šlo za neustrezno upravljanje vodnih virov. $\mathrm{V}$ enem primeru je bilo nestrinjanje posledica vzpostavitve nadzora kakovosti pitne vode in $s$ tem povezanih finančnih in upravljavskih stroškov. Prebivalci so se dogovorili in sprejeli ustrezno rešitev. Drug primer se je nanašal na globoko lokev s pitno vodo, ki so jo z napačnim gradbenim posegom skoraj uničili in $\mathrm{v}$ kateri voda ni več pitna, jo pa zdaj poskušajo sanirati. Zadnji primer je povezan $\mathrm{z}$ vodnim virom, od katerega je odvisna sosednja občina. Prebivalci so možnost črpanja pitne vode pogojevali z ureditvijo dela ceste, ki poteka po sosednji občini. Pereče je tudi vprašanje gozdov, ki so nekoč pripadali agrarni skupnosti in na katerih so lovišča, ki so v lasti države. Prebivalci se ne strinjajo z davčnimi bremeni za zemljišča, s katerimi ne smejo gospodariti.

\subsection{Dojemanje javnega in skupnega dobra med strokovno javnostjo}

Tudi strokovna javnost skoraj ne razlikuje med javnim in skupnim dobrom, a pri svojem delu večinoma uporablja izraz javno dobro, ki ga razume kot tisto, kar potrebujemo za preživetje, zato moramo imeti dostop do tega vsi. To so ceste, prometnice, (gozdne) vlake, poti, skratka infrastruktura, ki omogoča prehodnost in dostop do zemljiščc, gozdov, obale. Nekateri intervjuvanci so omenjali še mir, razglede, ohranjeno krajino, prostor, gozd in kmetijska zemljišča, naravo, ohranjene rastlinske in živalske vrste, vodo in preskrbo z njo, šole, trge ter drevnino in parke. Tudi strokovna javnost javno dobro povezuje pretežno z lastništvom in pogosto meni, da zaradi poseganja v zasebno lastnino lastnikom povzroča breme. Po mnenju strokovnjakinje za prostor zapleti lahko nastanejo tudi, ko je lastnica zadevnih javnih dobrin občina, drugih javnih dobrin pa država, kar kaže na potrebo po večnivojskem upravljanju.

Redka razmišljanja o skupnem dobru so se nanašala na tisto, kar uporabljajo skupno: ceste, skupne pašnike, travnike, gozdo- 
ve, tudi vodo in krajino. Torej, podobno, kar so omenjali že pri javnem dobru. Pri skupnem dobru so posamezniki izpostavili uporabo, ki lahko pride navzkriž z zasebnim interesom, predstavnica varstva kulturne dediščine pa je omenila, da se začnejo »ljudje skupnega dobra zavedati, ko ga začnejo izgubljati«. Dodatna asociacija na skupno dobro so bile agrarne skupnosti, ki upravljajo skupna zemljišča in dobrine (npr. les), ki jih lahko uporabijo člani agrarne skupnosti. Med koristmi skupnega dobra so posebej omenili gobe, beluši, možnost rekreacije in estetske vrednote v nekem okolju.

Tudi strokovna javnost se zaveda konfliktov, ki izhajajo iz pretirane in množične rabe javnega in skupnega dobra. Izpostavila je konflikt pri uporabi prireditvenega prostora ob sotočju Tolminke in Soče, ki je skoraj vse poletje v času festivalov zaprto. To jezi domačine, ki so se tam vedno lahko sprehajali in kopali, zdaj pa za to potrebujejo vstopnico. Na tem območju je tudi gozd s posebnim namenom, ki mu zaradi množičnega obiska festivalov grozi razvrednotenje. Predmet konfliktov so tudi nabrežja rek, ki so v Sloveniji prosto dostopne. Poleti jih obiskujejo obiskovalci iz različnih delov Slovenije, ki za sabo nemalokrat puščajo smeti, kar še dodatno razjezi domačine. Izpostavljen je bil problem uporabe reke Soče, kjer so bili v konfliktu ribiči, kajakaši in rafterji. Rešitev so našli v prostorski in časovni razmejitvi različnih dejavnosti. Verjetno bo treba podoben mehanizem upravljanja uporabiti pri rabi padalskih vzletišč, saj povečano število padalcev in čas zadrževanja na vzletnih točkah vznemirjata divjad. Vse večji konflikt ustvarja tudi nabiranje gob.

\section{Razprava}

Prvi cilj članka je bil pojasniti konflikte pri dojemanju nekaterih dobrin, za katere splošna javnost v Sloveniji meni, da so javno dobro, s čimer pa se lastniki ne strinjajo. Nesporazum smo želeli pojasniti z analizo prostorsko-časovne odvisnosti. Kot se je izkazalo, na dojemanje teh dobrin še vedno močno vplivajo lastništvo ter pojma družbena lastnina in samoupravljanje iz časa socialistične Jugoslavije, manj pa dogodki v agrarni dobi. Kot smo pričakovali, so v agrarni družbi, vsaj na območjih z večstoletno naselitvijo, upoštevali ranljivost naravnih virov, saj je bila trajnostna raba virov ključna za preživetje skupnosti. Domačini so se pri upravljanju omejenih naravnih virov največkrat organizirali v agrarne skupnosti in se s strogimi pravili uporabe skupnega izognili tragediji, ki jo je napovedoval Hardin (1968). Pokazali so, da je z omejenimi viri mogoče gospodariti tako, da se vir kljub uporabi nekaterih dobrin ohranja za prihodnje rodove, kar je pozneje na več mednarodnih primerih dokazala Ostromova (1990, 2005). Kljub temu je bila že takrat ponekod značilna čezmerna uporaba, in to predvsem zaradi slabega poznavanja vira in razdelitev zemljišč. Takšen primer je uničenje šote na Ljubljanskem barju v drugi polovici 19. stoletja, ko so nove lastnike vodile predvsem gospodarske koristi. Omejeni naravni viri, npr. pitna voda, lokve, gozdovi in pašniki, so še danes pomembni za kakovost življenja. Na pilotnem območju v Čadrgu so staro prakso skupnostnega upravljanja omejenih virov prenesli v sodoben čas. Uspešno upravljajo skupne gozdove, pašnike in vodo, pesti pa jih nerazumevanje države, ki jih na eni strani spodbuja k vpisu skupnih gozdnih zemljišč v zemljiško knjigo, po drugi strani pa jim ne priznava pravice do soodločanja pri upravljanju divjadi.

V industrijski dobi je v Sloveniji, ki je bila takrat del Jugoslavije, nastal lastninski konflikt med kmeti na eni in državo na drugi strani zaradi uveljavljanja koncepta družbene lastnine. Tega koncepta ne smemo enačiti s konceptom skupnega iz agrarne dobe, saj je koncept družbene lastnine temeljil na delu, koncept skupnega pa na skupnostnem upravljanju omejenih virov, ki so bili v skupni lasti. Caffentzisem (2010) pravi, da je socialistična ideologija ustvarila podobo skupnega gospodarjenja z viri, ki pa je v resnici temeljilo na restriktivnem upravljanju na podlagi birokratskih ali povsem kapitalističnih kriterijev. Podobno je trdil Pučnik (1963), ki je odpravo zasebnega lastništva na podeželju povezoval s socialno krivico in ekonomsko diskriminacijo kmečkega prebivalstva. Odprava agrarnih skupnosti in podržavljanje skupnih zemljišč po drugi svetovni vojni potrjujeta ugotovitev Obeng-Odooma (2016), da nevarnost za obstoj ne preti od znotraj, temveč je zunanja. Le da v Sloveniji odprava ni bila posledica kapitalizma ali imperializma, temveč jih je, ironično, odpravil komunizem. Prenos lastništev in/ali upravljanja na javne ustanove se je mnogokrat izkazal za problematičnega (npr.Zlatkova, 2015; Simoneti, 2016). Po eni strani so viri (p)ostali lastninsko v družbeni lasti, a ker se niso zavedali njihove ranljivosti, je bilo upravljanje pogosto slabo dorečeno brez ustreznih pravil in sankcij, kar je vodilo v propadanje. Na podeželju se je to na primer kazalo kot zaraščanje kmetijskih površin zaradi ideološke podpore industrializaciji, $\mathrm{v}$ mestih pa kot razvrednotenje skupnih zelenih površin ob večstanovanjskih stavbah. Za posledice slabšega upravljanja ali celo odsotnosti upravljanja so najbolj odgovorne » oddaljene « javne ustanove, ki zaradi pomanjkanja znanja in šibkih osebnih vezi niso prepoznale, da imajo tovrstni naravni viri lastnosti skupnih virov. Intervjuji z domačini kažejo ta še vedno trajajoči konflikt, saj praviloma grajajo ravnanje države z omejenimi naravnimi viri (npr. gozdovi, vodo) in menijo, da ni dober gospodar.

Kot upor socialistični kolektivizaciji so postsocialistične države navdušeno sprejele neoliberalizem (Smith in Timár, 2010), kjer ima država precej manjš̌e možnosti usmerjanja lokalnega in regionalnega razvoja kot $\mathrm{v}$ planskem gospodarstvu (Drozg, 2005). Znani so pritiski lastnikov gozdov, da se uporaba gozdnih sadežev omeji na lastnike (Kumer, 2017). V poglavju 5.2 
smo že omenili primer zapiranja prostora ob sotočju Soče in Tolminke v času festivala, kar je za slovensko javnost nerazumljivo in pomeni nezakonito prilaščanje skupnega prostora, ki ga domačini uporabljajo za sprehode in sprostitev. Koncesionar si je s plačilom uradno kupil pravico do omejitve gibanja za neobiskovalce festivala, vendar bi morala občina upoštevati, da imajo do prostora pravico tudi domačini, in temu primerno prilagoditi upravljanje. Na podlagi analize prostorsko-časovne odvisnosti v treh obdobjih ugotavljamo, da so posledice spreminjanja vpliva in moči posameznikov, skupnosti in ustanov na upravljanje omejenih virov v Sloveniji še danes vidne v različnem dojemanju javnega dobra in skupnega ter posledično tudi v različnih pričakovanjih javnosti in lastnikov do tovrstnih dobrin.

V intervjujih z domačini in strokovno javnostjo smo ugotavljali, kaj ti razumejo kot javno in skupno dobro, kar je bil drugi cilj članka. Izkazalo se je, da med pojmoma skoraj ne razlikujejo in ju dojemajo kot nekaj, kar je prosto dostopno. Razlikovanje je vezano predvsem na lastninsko pravico in gospodarsko korist, $s$ čimer se skupno dobro pomensko približuje skupnemu. Predvidevamo, da je to posledica prostorsko-časovnega konteksta in procesov, ki so oblikovali in še oblikujejo dojemanje skupnega in njihovega lastništva (agrarne skupnosti, nacionalizacija, denacionalizacija ipd.). Domačini skupno dobro pogosto enačijo s skupnimi stvarmi in ju uporabljajo kot sinonima. Za skupno je značilna skupna lastnina, pri čemer je dobrina, odvisno od (ne)dostopnosti, lahko zasebna ali pa skupni vir, ni pa javno dobro. Gozd v lasti agrarne skupnosti in zelene površine v blokovskih soseskah so zaradi proste dostopnosti skupni vir, ograjen skupni pašnik in sirarna pa ne, ker je dostop do njiju omejen. Na vseh treh pilotnih območjih domačini veliko truda namenjajo obstoju in nadgradnji skupnega; dejavno prostovoljno sodelujejo v skupnih akcijah in se zavedajo, da so pri izboljšanju kakovosti življenja odvisni predvsem od sebe in svojih, tudi finančnih vložkov. V preteklih desetletjih so si sami ali z lastnimi sredstvi zgradili vodovode, telefonsko napeljavo, elektriko, ponekod celo ceste. Vlagajo v obnovo in vzpostavitev kolesarskih in pohodnih poti, čistijo okolico, obnavljajo stare suhe zidove, vzdržujejo in gradijo skupne prostore. Nekatere stvari so si domačini pripravljeni deliti med seboj, zmoti pa jih, če se kdo želi okoristiti s pridobitvami njihovega skupnega dela in prispevkov. To kaže na pomembno vlogo skupnega pri izboljšanju kakovosti življenja domačinov. Pozitiven odnos do skupnega soustvarjanja in obnavljanja lastne okolice, ki jo upravlja skupnost, je nedvomna lastnost slovenskega podeželja. Skupno je v Sloveniji razumljeno več kot le skupna lastnina, saj gre za skupne vaške stvari, kar dodatno krepi skupnost in soustvarja lokalno identiteto.

Podobno smo tudi med strokovno javnostjo zaznali povezovanje skupnega dobra s skupno uporabo in z ustanovami, ki upravljajo skupna zemljišča (npr. agrarne skupnosti). Dobro se zaveda konfliktov, ki izhajajo iz povečane ali neopredeljene rabe nekaterih dobrin (npr. prostor, pitna voda, gobe), in ugotavlja, da je za reševanje tovrstnih konfliktov potreben dialog $\mathrm{z}$ vsemi vpletenimi, čemur mora slediti večnivojsko upravljanje. A kot ugotavlja Rodelova (2012), ključne odločitve glede skupnih virov v Sloveniji še vedno sprejemajo državne ustanove (zavodi, ministrstva, agencije), njihove resorne politike in razvojne programe pa izvajajo na dislociranih enotah. Ta način upravljanja skupnih virov je dediščina socializma, v katerem je centralizirani državni aparat okrepil svojo moč in veljavo. Alternativa tovrstnemu upravljanju so sodobni tuji modeli kompleksnega upravljanja skupnih virov, ki temeljijo na konceptih, kot so soupravljanje (Somerville in Haines, 2008), večaktersko upravljanje (Schut idr., 2014) ali večnivojsko upravljanje (Hooghe in Marks, 2003). Ključna pri omenjenih konceptih sta vzajemno oblikovanje in zastopanje različnih skupnosti, da bi uvedli učinkovitejše politike upravljanja skupnih virov.

Tretji cilj članka je bil opozoriti na jasno razliko med javnim dobrom in skupnimi viri, da bomo razumeli, zakaj prosto dostopne dobrine, ki so skupni viri, niso javno dobro in zato ne morejo biti neomejeno dostopne vsem. Obdobje socializma je $s$ poudarjanjem socialne in prostorske pravičnosti, enakosti in dostopnosti dobrin za vse (Drozg, 2005) okrepilo mnenje javnosti, da sta dostop in koriščenje tovrstnih dobrin (npr. gozdni sadeži, dostop do obale in podobno) njihova neodtujljiva pravica. Težava nastopi, ker javnost te dobrine še vedno dojema kot javno dobro in se ne zaveda negativnih posledic pretirane in neustrezne rabe. To potrjuje Heinmillerjevo (2009) ugotovitev, da pretekli vzorci lahko vplivajo na zakoreninjena razumevanja, pogosto povezana s starimi pravicami. V Sloveniji smo $v$ agrarni dobi že poznali skupnostno upravljanje omejenih virov, ki je bilo v socializmu prepovedano in nadomeščeno $\mathrm{z}$ upravljanjem vsega kot družbene lastnine brez zavedanja o omejenosti naravnih virov. Danes čutimo posledice obeh praks, ki se krešejo in vplivajo na trenutna dojemanja in pričakovanja splošne in strokovne javnosti, odločevalcev ter lastnikov zemljišč. Kljub mnogim slabostim preteklega sistema smo avtorji članka dobrine, kot so prost dostop do obal rek in jezer ter do gozda, možnost sprehodov po gozdu in pešpoteh zunaj gozda, nabiranje gozdnih sadežev v dovoljenih količinah in podobno, prepoznali kot pomemben privilegij preteklega sistema in prednost, ki splošni javnosti ključno izboljǔuje kakovost življenja, lastnikom pa ne povzroča škode. Na podobne privilegije do zemlje je opozarjal že George konec 19. stoletja (navedeno v Obeng-Odoom, 2016), Ostromova in njeni sodelavci pa se z njimi praviloma niso ukvarjali. Za ohranitev teh privilegijev je zato ključno ozavestiti javnost, da naštete dobrine niso javno dobro, torej nekaj, do česar imajo dostop vsi, in to v neomejenih količinah, temveč imajo te dobrine zaradi prostega dostopa in omejenosti lastnosti skupnih virov. 
Preglednica 1: Slovarček pojmov

\begin{tabular}{llll}
\hline $\begin{array}{l}\text { Izraz v slovenskem } \\
\text { jeziku }\end{array}$ & $\begin{array}{l}\text { Izraz v angleškem } \\
\text { jeziku }\end{array}$ & Kratka razlaga & Primer \\
\hline javno dobro & public good & $\begin{array}{l}\text { Dobrina, do katere dostopa ni mogoče preprečiti in se } \\
\text { njena razpoložljivost z uporabo ne manjša. }\end{array}$ & UV sevanje, mir, cesta, varnost ... \\
\hline skupni vir(i) & $\begin{array}{l}\text { common-pool } \\
\text { resource(s) (CPRs) }\end{array}$ & $\begin{array}{l}\text { Dobrina, do katere dostopa ni mogoče preprečiti in se } \\
\text { njena razpoložljivost z uporabo manjša. }\end{array}$ & $\begin{array}{l}\text { gozdni sadeži, pitna voda, dostop } \\
\text { do obale, prosto dostopne zelene } \\
\text { površine v blokovskih soseskah ... }\end{array}$ \\
\hline skupno & commons & $\begin{array}{l}\text { Posebna oblika zasebne lastnine v skupni rabi, ki jo } \\
\text { upravlja skupnost po določenih pravilih; skupno so } \\
\text { lahko skupni vir (npr. gozdni sadeži), ni pa nujno, lahko } \\
\text { gre za povsem zasebno dobro (npr. sirarna). }\end{array}$ & $\begin{array}{l}\text { vaški nasad orehov, skupna zemlji- } \\
\text { skupnostni vrtički ... }\end{array}$ \\
\hline
\end{tabular}

Obenem moramo ozavestiti tudi lastnike, da jim lastništvo še ne podeljuje neomejene pravice uporabe naravnih virov. $\mathrm{Za}$ radi želja po privatizaciji, koncesijah in licenčninah, ki zaradi gospodarskih interesov močno ogrožajo naše omejene naravne vire, se splošna javnost v Sloveniji upravičeno boji. Zgovoren odpor na takšne težnje je vpis pravice do pitne vode v Ustavo RS (Ustavni zakon o dopolnitvi III. poglavja Ustave Republike Slovenije, Ur. l. RS, šst. 75/2016), vendar je treba ob tem izpostaviti, da ustavodajalec ne razume, da voda ni javno dobro, temveč omejeni naravni vir. Prav ta lastnost, ki jo slovenska javnost zaznava intuitivno, je bila gonilo prizadevanj za vpis pravice do vode $\mathrm{v}$ Ustavo RS. Vendar vpis vodnih virov še ne bo zaščitil, saj ti ostajajo ranljivi in omejeni. Maja in julija 2017 sta slovensko javnost pretresli dve ekološki katastrofi, ki sta poleg prsti in zraka prizadeli tudi vodne vire. Pokazalo se je, da le sprememba zakonodajnega okvira s pripadajočimi podzakonskimi akti ni dovolj. Potrebni bodo konkretne prilagoditve, jasna pravila, nadzor in ne nazadnje sankcije nad neustreznim upravljanjem vodnih virov. Pereč primer v Sloveniji je tudi spreminjanje rodovitnih zemljišč v industrijska območja. Vsaka taka investicija zahteva tehten premislek, saj so rodovitna zemljišča naši naravni viri, njihovo razvrednotenje pa nepovratno. Zaradi povečanja števila uporabnikov in nasprotij interesov so v urbanem okolju izpostavljene zelene površine ob večstanovanjskih stavbah.

S tem člankom želimo opozoriti, da nam v primeru neupoštevanja omejenosti dobrin grozita siromašenje in izčrpavanje teh dobrin ali virov. Včasih lahko siromašenje, predvsem z ekosistemskega vidika, povzroči tudi delitev virov v manjše enote. $\mathrm{V}$ izogib temu so predniki za uporabo omejenih naravnih virov razvili skupnostno upravljanje s točno določenimi pravicami in pravili. Razdelili so si donose, na primer drva, ne pa tudi zaloge skupnega vira, $\mathrm{v}$ tem primeru gozda. To potrjuje ugotovitev McKeanove (2000), da so privatizirali pravice do dobrine, ne da bi jo razdelili na manjšs dele. Na tem konceptu je temeljila tudi družbena lastnina v socializmu, a s to razliko, da pravica ni bila prenosljiva in je ugasnila s prenehanjem delovnega raz- merja. Sodoben in aktualen primer upravljanja skupnih virov iz urbanega prostora so blokovske zelene površine. Ponekod se stanovalci organizirajo, posadijo grmovnice in drevesa, ne da bi obenem razdelili zelenico, saj bi bil posamezen delež zemljišča premajhen za posaditev drevesa. $S$ pravili, pogoji in sankcijami se vključijo v upravljanje svoje zelenice, ki ni javno dobro, temveč skupni vir. Kjer se stanovalci ne organizirajo, tvegajo razvrednotenje zelenih površin v svoji neposredni okolici. Skupina ljudi gre lahko še korak dlje, izbere, najame ali kupi zemljiščce ter na njem zasadi orehe, kot v Čadrgu, v urbanih soseskah pa zelenjavo in sadje. Plodovi, ki dozorijo na teh zemljiščih, niso javno dobro. So tipična skupna lastnina ali skupno, a kljub temu, da se ve, kdo jih lahko koristi, imajo zaradi omejenosti dobrine v primeru prostega dostopa lastnosti skupnih virov. Podobno tudi plodovi v mestnem sadovnjaku, zasajenem v Ljubljani na Viču, ki je bil zaradi prešibkega upravljanja že nekajkrat žrtev vandalizma, čeprav je zasajen na javnih površinah, niso javno dobro, temveč so zaradi omejenosti dobrine in proste dostopnosti skupni viri. Zaradi omejenosti in proste dostopnosti tudi borovnice, gobe in kostanji v gozdu niso javno dobro, temveč skupni viri. V izogib nadaljnjim nejasnostim v zvezi z javnim dobrom, skupnimi viri in skupnim ter v podporo ustreznejšemu upravljanju smo v preglednici 1 pripravili kratke razlage ključnih pojmov.

V sklepu razprave želimo izpostaviti še vlogo lastništva. Kot je navedeno v teoretičnih izhodiščih, sta ključni lastnosti dobrin manjša/večja dostopnost in manjšse/večje zmanjševanje z rabo, ne pa tudi lastništvo. Vendar se vloga lastništva uveljavi pri upravljanju, ko lahko lastnik omeji dostop do vira ali dobrine. Privatizacija omejenega naravnega vira zaradi gospodarskih interesov posameznika ali manjšine lahko vodi $\mathrm{v}$ izčrpavanje vira, od katerega je odvisna lokalna skupnost. Ni vseeno, kdo odloča o dostopu do vira in njegovega upravljanja. Že predniki so se zavedali, kako pomembno je, da imajo lokalne skupnosti lastništvo nad omejenimi naravnimi viri v svoji neposredni okolici. Tega se zavedajo domačini v Čadrgu, ki so z velikimi prizadevanji ohranili pravico do upravljanja vodnih 
virov. Duraippah idr. (2014) omenjajo, da se v zadnjem času na Japonskem vzpostavlja koncept novega skupnega (ang. new commons), ko skupina posameznikov začne skupno upravljati zapuščene zarǎ̌čene površine.

\section{Sklep}

Analiza prostorsko-časovne odvisnosti je pokazala, da sta pretekli družbenogospodarski ureditvi nedvomno vplivali na sedanje dojemanje javnega dobra in skupnega, kar moramo upoštevati pri nadaljnjem upravljanju. Bogata zgodovina agrarnih skupnosti je v Sloveniji prek skupnih zemljišč uvedla raznovrstno upravljanje omejenih naravnih virov. Socialistična dediščina se kaže v poudarjanju pravičnosti dostopa do dobrin za vse prebivalce, ki mnoge dobrine dojemajo kot javno dobro in imajo lahko skladno s tem prepričanjem neupravičena pričakovanja. Dodaten vpliv preteklega sistema je še vedno opazen v togem in centraliziranem državnem upravljanju. Postsocialistično obdobje je prineslo denacionalizacijo, ponovno obujanje skupnostnega upravljanja omejenih virov, a tudi divjo privatizacijo različnih dobrin z željo po gospodarskih dobičkih za posameznike in manjšine. To je v Sloveniji povzročilo bojazen splošne javnosti po privatizaciji vode, kar je vodilo $\mathrm{k}$ vpisu pravice do vode v Ustavo RS. Po drugi strani pretirano nabiranje gozdnih sadežev in nespoštljiva raba gozdov jezita lastnike in vplivata na kostanjeve in gobarske vojne, ki so posledica omenjenih zgodovinskih dejavnikov.

Na podlagi raziskave o dojemanju javnega in skupnega dobra med domačini in strokovno javnostjo smo ugotovili, da glavno razliko med tema dvema pojmoma intervjuvanci pripisujejo lastništvu, pri čemer strokovna javnost presoja z vidika lastne soudeležbe ali neposredne koristi. Skupno dobro domačini in strokovna javnost dojemajo kot tisto, kar je last lokalne skupnosti ali ta to upravlja, kar pojem približuje pojmu skupnega. Takoj ko se lastništvo prenese na javno ustanovo (npr. občino ali ministrstvo), $v$ očeh širše javnosti to postane javno dobro.

V izogib konfliktom, razvrednotenju omejenih naravnih virov in morebitni izgubi privilegijev, ki nam izboljšujejo kakovost življenja, si avtorji prispevka prizadevamo slovensko splošno in strokovno javnost ozavestiti o razlikovanju med javnim dobrom in skupnimi viri. Razumevanje o razlikovanju teh dveh pojmov je treba vključiti v izobraževalni sistem ter v druge izrazne oblike in vsebine. Ob podrobnem pregledu se pokaže, kako malo dobrin v resnici spada med javno dobro. Marsikateri naravni viri niso bili ogroženi več stoletij, dokler jih človek ni znal uporabljati ali pa je bila raba zanemarljiva. Dokler splošne in strokovne javnosti ne ozavestimo, da je poleg proste dostopnosti ključna lastnost skupnih virov omejenost, njihovo upravljanje ne bo ustrezno in lahko vodi v izrabo, kar bo na koncu najbolj prizadelo lokalne skupnosti, ki so odvisne od teh virov. Javnost mora razumeti, da so številne dobrine, ki jih trenutno dojema kot javno dobro, v resnici skupni viri, ki so prosto dostopni, a omejeni. Do rabe tovrstnih virov, ki nikakor ni samoumevna, mora javnost privzeti spoštljiv odnos. Le ustrezno upravljanje z jasno določenimi pravicami rabe ohranja in vzdržuje skupne vire, zato je ključno, da javnost razume 1) bistvo javnega dobra in skupnih virov ter 2) vloge skupnostnega upravljanja pri trajnostnem gospodarjenju $\mathrm{z}$ viri. To razumevanje bi morali s podeželja prenesti v urbana območja in ga je treba upoštevati pri upravljanju urbanih območij, kot so zelene površine ob blokovskih soseskah, javnih sadovnjakov, skupnostnih vrtov ipd. V mednarodnem okolju želimo $s$ predstavljenim slovenskim primerom prispevati $\mathrm{k}$ boljšemu razumevanju človeškega vedenja in pričakovanj do javnega dobra ter skupnih virov $\mathrm{v}$ postsocialističnih tranzicijskih družbah. Ključno vlogo pri tem imata družbenogospodarski in politični kontekst $s$ pripadajočimi ideologijami.

\section{Mateja Šmid Hribar \\ Znanstvenoraziskovalni center Slovenske akademije znanosti in umetnosti, Geografski inštitut Antona Melika, Ljubljana, Slovenija E-naslov: mateja.smid@zrc-sazu.si}

\section{Jani Kozina}

Znanstvenoraziskovalni center Slovenske akademije znanosti in umetnosti, Geografski inštitut Antona Melika, Ljubljana, Slovenija E-naslov: jani.kozina@zrc-sazu.si

\section{David Bole}

Znanstvenoraziskovalni center Slovenske akademije znanosti in umetnosti, Geografski inštitut Antona Melika, Ljubljana, Slovenija E-naslov: david.bole@zrc-sazu.si

\section{Mimi Urbanc}

Znanstvenoraziskovalni center Slovenske akademije znanosti in umetnosti, Geografski inštitut Antona Melika, Ljubljana, Slovenija E-naslov:mimi.urbanc@zrc-sazu.si

\section{Zahvala}

Avtorji se zahvaljujemo dvema anonimnima recenzentoma za koristne napotke pri izboljševanju vsebinske pestrosti in jasnosti članka. Hvaležni smo tudi za finančno podporo projekta Kulturna pokrajina v precepu med javnim dobrim, zasebnimi interesi in politikami, št. J66854, in raziskovalnega programa št. P6-0101, ki ju je sofinancirala Javna agencija za raziskovalno dejavnost Republike Slovenije iz državnega proračuna.

\section{Viri in literatura}

Anderies, J. M., in Janssen, M. A. (2012): Sustaining the Commons. Dostopno na http://sustainingthecommons.asu.edu/wp-content/uploads/2013/07/Sustaining-the-Commons-v101.pdf (sneto 1. 6. 2015).

Bogataj, N. (2012): Model delovanja slovenskih agrarnih skupnosti. V: Rodela, R. (ur.): Soupravljanje naravnih virov: vaške skupnosti in sorodne 
oblike skupne lastnine in skupnega upravljanja, str. 23-37. Wageningen, Wageningen University and Research Centre. Dostopno na http://edepot.wur.nl/205876 (sneto 10. 8. 2017).

Caffentzis, G. (2010): The Future of,The Commons': Neoliberalism's ,Plan B' or the Original Disaccumulation of Capital? New formations, 69, str. 23-41. DOI: 10.3898/NEWF.69.01.2010

Cerar, G., Kliner, P., in Papež, M. (2011): Prihodnost agrarnih skupnosti. Zelena dežela, 102, str. 7-10.

Czerny, T. A. (2014): Analiza skupnega upravljanja naravnih virov na primeru agrarne skupnosti Škrbina - Rubije - Šibelji. Magistrsko delo. Ljubljana, Univerza v Ljubljani, Biotehniška fakulteta.

Colloca, F., Cardinale, M., Maynou, F., Giannoulaki, M., Scarcella, G., Jenko, K., idr. (2013): Rebuilding Mediterranean fisheries: a new paradigm for ecological sustainability. Fish and Fisheries, 14(1), str. 89-109. DOI: 10.1111/j.1467-2979.2011.00453.x

Desmarais-Tremblay, M. (2014): On the definition of Public Goods. Assessing Richard A. Musgrave's contribution. Documents de travail du Centre d'Economie de la Sorbonne. Dostopno na https://halshs.archives-ouvertes.fr/halshs-00951577/document (sneto 29. 4. 2018).

Drozg, V. (2005): Koncepti policentrične ureditve Slovenije. Dela, 24, str. 147-158. DOI: 10.4312/dela.24.12.147-158

Drozg, V. (2007): Prispevek h gospodarski geografiji Slovenije. Revija za geografijo, 1/2(3), str. 67-88.

Dupré, L. (1993): The common good and the open society. The Review of Politics, 55(4), str. 687-712. DOI: 10.1017/S0034670500018052

Duraippah, A. K., Asah, S. T., Brondizio, E. S., Kosoy, N., O'Farrell, P. J., Prieur-Richard, A., idr. (2014): Managing the mismatches to provide ecosystem services for human well-being: a conceptual framework for understanding the New Commons. Current Opinion in Environmental Sustainability, 7, str. 94-100. DOI: 10.1016/j.cosust.2013.11.031

Fromentin, J. M. (2009): Lessons from the past: investigating historical data from bluefin tuna fisheries. Fish and Fisheries, 10(2), str. 197-216. DOI: $10.1111 / \mathrm{j} .1467-2979.2008 .00311 . x$

Godina, V. V. (2015): Zablode postsocializma. Ljubljana, Beletrina.

Grahek, S. (ur.) (1988): Komentar zakona o združenem delu. Ljubljana, Delo.

Hardin, G. (1968): The tragedy of the commons. Science, 162, str. 12431248. DOI: 10.1126/science.162.3859.1243

Heinmiller, B. T. (2009): Path dependency and collective action in common pool governance. International Journal of the Commons, 3(1): str. 131-147. DOI: 10.18352/ijc.79

Hooghe, L., in Marks, G. (2003): Unraveling the Central State, but How? Types of Multi-level Governance. American Political Science Review, 97(2), str. 233-243.

Jaede, M. (2017): The Concept of the Common Good. Dostopno na: http://www.politicalsettlements.org/publications-database/the-conceptof-the-common-good/ (sneto 10. 2. 2018).

Jepsen, M. R., Kuemmerle, T., Müller, D., Erb, K., Verburg, P. H., Haberl, H., idr. (2015): Transitions in European land-management regimes between 1800 and 2010. Land Use Policy, 49, str. 53-64. DOI: 10.1016/j.landusepol.2015.07.003

Klemenčič, M. M. (1989): Družbenogospodarski prehod v Sloveniji. Dela, 6, str. 230-243.

Klemenčič, M. M. (1997): Geografski prehod. Dela, 12, str. 15-29.

Kluvánková, T., in Gežík, V. (2016): Survival of commons? Institutions for robust forest social - ecological systems. Journal of Forest Economics, 24, str. 175-185. DOI: 10.1016/j.jfe.2016.01.002
Kumer, P. (2017): Vpliv družbenogeografskih dejavnikov na gospodarjenje z majhnimi zasebnimi gozdnimi posestmi. Doktorska disertacija. Ljubljana, Filozofska fakulteta, Oddelek za geografijo.

Lee, S. (2018): Common good. V: Encyclopædia Britannica. Dodstopno na: http://corporate.britannica.com/ (sneto 10. 2. 2018).

Lopes, L. L. G., Bento, J. M. R. S., Cristovão, A. F. A. C., in Baptista, F. O. (2013): Institutionalization of common land property in Portugal: Tragic trends between "Commons" and "Anticommons«. Land Use Policy, 35, str. 85-94. DOI: 10.1016/j.landusepol.2013.05.007

Lorenčič, A. (2009): Pretvorba družbene lastnine v privatno - osrednji problem slovenske gospodarske tranzicije. Prispevki za novejšo zgodovino, 49(2), str. 189-206.

McKean, M. (2000): Common Property: What is it? What is it good for? and What makes it work? V: Gibson, C. C., McKean M. A., in Ostrom, E. (ur): People and forest: Communities, Institutions, and Governance, str. 27-55. Cambridge (MA), The MIT Press.

Mansbridge J. (2013): Common Good. V: LaFollette H, (ur.): The International Encyclopedia of Ethics, Vol. II. Malden, MA, Wiley-Blackwell. DOI: 10.1002/9781444367072.wbiee608

Markuszewska, I. (2018): Conflicts between legal policy and rural area management in Poland. Acta geographica Slovenica, 58(1), str. 59-67. DOI: 10.3986/AGS.1525

Melik, A. (1927): Kolonizacija Ljubljanskega barja. Ljubljana, Tiskovna Zadruga.

Musgrave, R. A. (1969): Provision for social goods. Public Economics: An analysis of Public Production and Consumption and their Relations to the Private Sectors. London, Macmillan.

Musgrave, R. A., in Musgrave, P. (1973): Public Finance in Theory and Practice. New York, McGraw Hill.

Obeng-Odoom, F. (2016): The meaning, prospects, and future of the commons: Revisiting the legacies of Elinor Ostrom and Henry George. The American Journal of Economics and Sociology, 75(2), str. 372-414. DOI: 10.1111/ajes.12144

Omladič, L. (2016): Okoljska etika: kostanjeve vojne. Dostopno na http:// www.delo.si/novice/okolje/okoljska-etika-kostanjeve-vojne.html (sneto 16.8 . 2017).

Ostrom, V., in Ostrom, E. (1977): Public goods and public choices: The emergence of public economics and industry structures. V: Savas E. S. (ur.): Alternatives for Delivering Public Services: Toward Improved Performance. Boulder, Westview Press.

Ostrom, E. (1990): The governing of commons.The Evolution of Institutions for Collective Action. Cambridge, Cambridge University press. DOI: $10.1017 /$ CBO9780511807763

Ostrom, E. (2005): Understanding Institutional Diversity. New Jersey, Princeton University Press.

Ostrom, E. (2010): Beyond markets and states: Polycentric governance of complex economic systems. American Economic Review, 100(3), str. 641-672. DOI: 10.1257/aer.100.3.641

Partlič, S. (1989): „Znanost« v agrarni politiki Jugoslavije. Teorija in praksa 26, str. 3-4.

Pavšič, J. (2008): „Geologija barja in njegovega obrobja«. V: Pavšič, J. (ur): Ljubljansko barje - neživi svet, rastlinstvo, živalstvo, zgodovina in naravovarstvo, str. 6-16, Ljubljana, Slovenska matica.

Petek, F., in Urbanc, M. (2007): Common land in Slovenia. Geografski vestnik, 79(2), str. 41-62.

Premrl, T. (2013). Analiza stanja agrarnih skupnosti v Sloveniji na podlagi podatkov upravnih enot. Elaborat. Ljubljana, Gozdarski inštitut Slovenije. 
Premrl, T., Udovč, A., Bogataj, N., in Krč, J. (2015): From restitution to revival: A case of commons re-establishment and restitution in Slovenia. Forest Policy and Economics, 59, str. 19-26. DOI: 10.1016/j.forpol.2015.05.004

Pučnik, J. (1963): O dilemah našega kmetijstva. Perspektive, 4, str. 33-34.

Ravnik, M. (1998): Soseska. V: Javornik, M. (ur.): Enciklopedija Slovenije, 12, str. 158-159. Ljubljana, Mladinska knjiga.

Razpotnik Visković, N., in Seručnik, M. (2013): Respectability of the farming profession and part- time farmers in Slovene society after World War II. Geografski vestnik, 85(1), str. 25-36.

Rodela, R. (2012): Uvod v skupno lastnino in skupno upravljanje naravnih virov. V: Rodela, R. (ur.): Soupravljanje naravnih virov: vaške skupnosti in sorodne oblike skupne lastnine in skupnega upravljanja, str. 11-20. Wageningen, Wageningen University and Research Centre. Dostopno na http://edepot.wur.nl/205876 (sneto 16. 1. 2017).

Samuelson, P. A. (1954) The pure theory of public expenditure. The Review of Economics and Statistics 36(4), str. 387-389. DOI: 10.2307/1925895

Schut, M., Cunha Soares, N., van de Ven, G., in Slingerland, M. (2014): Multi-actor governance of sustainable biofuels in developing countries: The case of Mozambique. Energy Policy, 65, str. 631-643. DOI: 10.1016/j.enpol.2013.09.007

Sikor, T. (2004): The Commons in Transition: Agrarian and Environmental Change in Central and Eastern Europe. Environmental Management, 34(2), str. 270-280. DOI: 10.1007/s00267-003-3007-5

Simoneti, M. (2016): Celovit sistem ukrepov za urejanje javnih zelenih površin v slovenskih naseljih. Doktorska disertacija. Ljubljana, Univerza v Ljubljani, Fakulteta za gradbeništvo in geodezijo.

Small, J., Witherick, M. (1986): A Modern Dictionary of Geography. London, Hodder Arnold.

Smith, A., in Timár, J. (2010): Uneven transformations: Space, economy and society 20 years after the collapse of state socialism. European Urban and Regional Studies, 17(2), str. 115-125. DOI: $10.1177 / 0969776409358245$

Somerville, P., in Haines, N. (2008): Prospects for Local Co-Governance. Local Government Studies, 34(1), str. 61-79. DOI: 10.1080/03003930701770488

Šetinc, F. (1979): Misel in delo Edvarda Kardelja. Ljubljana, Prešernova družba.

Šmid Hribar, M. (2016): Varovanje in trajnostni razvoj kulturne pokrajine na primeru Ljubljanskega barja. Georitem 27. Ljubljana, Založba ZRC.

Šmid Hribar, M., Bole, D., in Urbanc, M. (2015): Public And Common Goods in the Cultural Landscape. Geografski vestnik, 87(2), str. 43-57. DOI: $10.3986 / G V 87203$

Tomšič, M., in Vehovar, U. (2012): Quality of Governance in »Old« and "New« EU Member States in a Comparative Perspective. Slovak sociological review, 44(3), str. 367-384.

Toplak, C. (2014): »Za nov družbeni red«: genealogija samoupravljanja. Ars \& humanitas, 8(1), str. 118-135. DOI: 10.4312/ah.8.1.118-135

Urbanc, M. (2002): Kulturne pokrajine v Sloveniji. Geografija Slovenije 5. Ljubljana, Založba ZRC.

Ustavni zakon o dopolnitvi III. poglavja Ustave Republike Slovenije (UZ70a). Uradni list Republike Slovenije, št. 75/2016. Ljubljana.

Vilfan, S. (1996): Zgodovinska pravotvornost in Slovenci. Ljubljana, Cankarjeva založba.

Vugrin, M. (2005): Definiranje pojma javno dobro (Definition of term public good). Geodetski vestnik, 49(3), str. 416-423.
Zakon o agrarni reformi in kolonizaciji. Uradni list LRS, št. 10/1948, 17/1958, 17/1959, 18/1961 in 22/1965. Ljubljana.

Zakon o agrarnih skupnostih. Uradni list LRS 52/1947. Ljubljana.

Zakon o denacionalizaciji. Uradni list RS, št. 27/1991-I, 56/1992 - odl. US, 13/1993 - odl. US, 31/1993, 24/1995 - odl. US, 20/1997 - odl. US, 23/1997 - odl. US, 65/1998, 76/1998 - odl. US, 66/2000, 66/2000 ORZDen27, 11/2001 - odl. US, 54/2004 - ZDoh-1 in 18/2005 - odl. US. Ljubljana.

Zakon o kmetijskem zemljiškem skladu splošnega ljudskega premoženja in o dodeljevanju zemlje kmetijskim organizacijam. Uradni list FLRJ, št. 22/1953. Ljubljana.

Zakon o razpolaganju s premoženjem bivših agrarnih skupnosti. Uradni list SRS, št. 7/1965. Ljubljana.

Zakon o združenem delu (ZZD). Uradni list SFRJ, št. 53/1976. Ljubljana.

Zakon o upravljanju državnih in gospodarskih podjetij in višjih gospodarskih združenj po delovnih kolektivih. Uradni list FLRJ, št. 43/1950. Ljubljana.

Zlatkova, I. M. (2015): Gardening the City: Neighbourliness and Appropriation of Common Spaces in Bulgaria. Colloquia Humanistica, 4, str. 41-60. DOI: 10.11649/ch.2015.012 